\title{
AN INTERPRETATION OF EVIL'S PERCEPTION IN THE FREEDOM ESSAY OF FRIEDRICH SCHELLING
}

\author{
Ph.D. Georgios KARAKASIS, \\ Doctor in Philosophy, University of the Basque Country, \\ SPAIN \\ E-mail: Geokarakasis7@yahoo.com
}

\begin{abstract}
The aim of this paper is to bring into light the significance of Schelling's Freedom Essay for our understanding of how evil is to be perceived and which its nature is. More specifically, in the first part we will start by presenting the distinction made by the German philosopher between the ground and the existence of God so as to show the way human being rises as pure potentiality from the ground of God. In the second part we will examine how what was a pure potentiality and blind will, namely the human being in the ground, enlightened by the rays of the understanding, of the Word as universal will, gets to know itself and become aware of its own willing as such. Once what was a blind will in the ground gets touched by the light of understanding, it is shone forth by the latter's spirit. Hence, we witness the becoming of the human being from a mere selfhood to a personality; a radical change accompanied by the self-aware human being's will to will either his subordination to what has made his self-awareness feasible or his decision to make himself the centre of all existence. Thus, the - firstly ground-grounded blind will becomes a powerful will able to freely will something, even though this something is evil. In the last part we will examine the challenges the evil sets in modern society and we will highlight the necessity of an interdisciplinary approach towards our understanding of what evil and its relation with modern society's human being is.
\end{abstract}

Keywords: Schelling; Ground; Existence; Evil; Freedom; Modern world;

\section{INTRODUCTION}

The aim of this paper is, firstly, to present - via an extended reference to passages how the concept of evil is interpreted in Friedrich Schelling's Freedom Essay ${ }^{l}$, as well as why it is perceived as purely spiritual, and, secondly, to highlight the work's diachronic significance for our better grasping both in philosophy and religious studies of the emergence of evil in modern society.

In the first part we will set out and probe into the famous distinction between the ground and the existence ${ }^{2}$ of God, seeking to understand how the human being's ascend

\footnotetext{
1 The Freedom Essay, being written in a very particular theological/cryptic vocabulary has also provoked great interest due to its potential influence from the thought of the mystic and philosopher Jacob Böhme. For a very detailed and well based analysis of this subject see: S.J McGrath, The Dark Ground of Spirit: Schelling and the Unconscious, London: Routledge, 2012

${ }^{2}$ For very insightful and clarifying interpretations of these two concepts in the Freedom Essay see the following: Martin Heidegger, Schelling's treatise on the essence of human freedom, Ohio: Ohio University Press, 1985 and Jason Wirth, The conspiracy of life: Meditations on Schelling and His Time, Albany: State University of New York Press, 2003.
} 
springs from as pure potentiality from the former. The aforementioned distinction, due to its multiple aspects - such as dark and light principle, gravity and light, blind will and understanding, among others - is of crucial importance when it comes to see the way the human being is related to God in the thought of the German philosopher.

In the second part we will show the process of human being's becoming a personality through his merging into the spirit. The latter - being dark ground's passage to(wards) its self-enlightenment when brought into light by the light principle of understanding becomes, too, the only way through which evil's apparition to the human being is manifested in the latter's free will to make of himself the centre of the universe.

In the last part, we will ponder over the turbulent and bloody situations the world has been living since the beginning of the $20^{\text {th }}$ century and we will set forth our proposal for the necessity of an interdisciplinary reinterpretation of the human being and of the way evil is emerging in modern society. More specifically, our intention is to highlight the importance of perceiving and treating the human being as a pure living will; not as an abstract concept of Spirit's unfolding in the world, but as a corporeal entity extremely capable of suffering and provoking suffering as well.

\section{THE DARK GROUND OF GOD: GROUND AND EXISTENCE IN THE FREEDOM ESSAY}

In this first part we will see one of the most important elements appearing in the Freedom Essay, the distinction between the ground and the existence - first in God, then in the human being - which, when being fully actualized, opens the overwhelming infinity of possibilities of action for the human subject. This distinction - described in a variety of ways - aims at helping us realize why this division is crucial for our understanding of freedom and evil's essence. Some of the abovementioned distinctions are: dark and light principle, yearning and understanding, contraction and expansion etc. The reason of our emphatic insistence on the distinction made is that it paves the way for our becoming conscious of the unity's critical role as interplay in the thought of Schelling. Evil is not to be seen as mere deficiency or a tool for the final victory of good. Evil is rooted much deeper into our yearning for becoming and it is chosen freely, as we will later see. Coming now back to the distinction between ground and existence, Schelling's comment is:

"This ground of his existence, which God has in himself, is not God considered absolutely, that is, in so far as he exists; for it is only the ground of his existence. It [the ground] is nature - in God, a being indeed inseparable, yet still distinct, from him. This relation can be explained analogically through that of gravity and light in nature. Gravity precedes light as its ever dark ground, which itself is not actu [actual], and flees into the night as the light (that which exists) dawns. Even light does not fully remove the seal under which gravity lies Contained. Precisely for this reason gravity is neither the pure essence nor the actual Being of absolute identity but rather follows only from its own nature or is absolute identity, namely considered as a particular potency"3.

What we can derive from the examination of this difficult, and rather cryptic passage, is that God's existence is not nullifying His ground of existence. The ground of God - nature - even though inseparable from God is not something actual. It is of a particular potency; a potency that gets actualized in the appearance and the actions of beings - most importantly, human beings.

\footnotetext{
${ }^{3}$ Friedrich Schelling, Philosophical Investigations Into the Essence of Human Freedom (translated by J. Love and J. Schmidt), Albany: State University of New York Press, 2006, p. 28
} 
This distinction between the existence of God and the ground of His existence is quintessential in the Freedom Essay since it succours us in discerning how things come to be(come). Namely,

"We recognize rather that the concept of becoming is the only one appropriate to the nature of things. But they cannot becomein God, considered in an absolute manner, since they are different from him toto genere or infinitely, to speak more correctly. In order to be divided from God, they must become in a ground different from God. Since, however, nothing indeed can be outside of God, this contradiction can only be resolved by things having their ground in that which in God himself is not He Himself, that is, in that which is the ground of his existence" $"$.

In this passage a key claim is made: no thing can exist outside of God, but all of the things are different essentially from God. How can we manage to understand what things are and how the process of their becoming operates? Only through their coming from, their emergence from the ground of God's existence. This is the way Schelling tries to explain how things come to be, and their relation with(in) God. In an effort to make this point a bit clearer for our perception says:

"If we want to bring this way of being closer to us in human terms, we can say: it is the yearning the eternal One feels to give birth to itself. The yearning is not the One itself but is after all co-eternal with it. The yearning wants to give birth to God, that is, unfathomable unity, but in this respect there is not yet unity in the yearning itself. Hence, it is, considered for itself, also will; but will in which there is no understanding and, for that reason, also not independent and complete will, since the understanding is really the will in will", .

The distinction between ground and existence wears another really important aspect here: yearning and understanding. The yearning of the One is not God as existence since there is no understanding and without understanding there can be no unity. The understanding appears only in its brilliance with the pronouncing of the Word, the personal self-revelation of God, where the light of the understanding is lights up(on) the darkness of the ground of God's existence. But the yearning of the ground, this blind will which blindly wills only itself is not unity; only through the understanding comes unity, only through the Word as accounted for in the following passage:

"But, corresponding to the yearning, which as the still dark ground is the first stirring of divine existence, an inner, reflexive representation is generated in God himself through which, since it can have no other object but God, God sees himself in an exact image of himself. This representation is the first in which God, considered as absolute, is realized [verwirklicht], although only in himself; this representation is with God in the beginning and is the God who was begotten in God himself. This representation is at the same time the understanding - the Word — of this yearning and the eternal spirit which, perceiving the word within itself and at the same time the infinite yearning, and impelled by the love that it itself is, proclaims the word so that the understanding and yearning together now become a freely creating and all-powerful will and build in the initial anarchy of nature as in its own element or instrument". 6

This is how God, and only God, exists in the perfect unity between the yearning of the ground of His existence and the understanding which radiantly shines forth from the Word. What is perfect in God, though, is very different if compared with what is perfect in the human being; far from being perfect, the human being, unable for ever to reach the perfect unity occurring in God, can only strive between his own yearning and his will to be shed in light in the radiance of the understanding of the Word. Nevertheless, it is in thus struggle that

\footnotetext{
${ }^{4}$ Friedrich Schelling, Philosophical Investigations.., p.28

${ }^{5}$ Friedrich Schelling, Philosophical Investigations..,p.30

${ }^{6}$ Friedrich Schelling, Philosophical Investigations.., p.30
} 
freedom appears carrying with it the possibility of acting evil- but the possibility of freely overcoming what evil is as well. In the following passage we will see how Schelling comprehends the emergence of the beings and the interplay of the yearning and understanding in them.

"Each being having emerged in nature according to the manner indicated has a dual principle in itself which, however, is basically but one and the same considered from both possible sides. The first principle is that through which things are separated from God or through which they exist in the mere ground; since, however, an original unity indeed occurs between what is in the ground and what is prefigured in the understanding, and the process of creation involves only an inner transmutation or transfiguration of the initial principle of darkness into the light (because the understanding or the light placed in nature genuinely seeks in the ground only the light that is related to it and turned inward), the-by its nature-dark principle is exactly what is transfigured in the light, and both are, though only to a certain point, one in each natural being. The principle, to the extent that it comes from the ground and is dark, is the self-will of creatures which, however, to the extent that it has not yet been raised to (does not grasp) complete unity with the light (as principle of understanding), is pure craving or desire, that is, blind will. The understanding as universal will stands against this self-will of creatures, using and subordinating the latter to itself as a mere instrument"

In the above passage we observe the appearance of the human being as a magnificent being indeed; one which yearns, wills blindly but also in an enlightened manner when he wills the Word - the universal will- and his subordination to it. This struggle between the ground - the blind self-will- and the understanding is the whole history of human life on the world. Our life is a twofold strife: a) the revelation of the light to the blind will, so that the latter be up in knowing what it wills, and b) the decision - which is the proof of how tragedy and brilliance coexist in our lives - to choose what we want to will after the light of the Word has sent its rays on the ground. In other words, whether we will choose to will good or evil. Quoting Schelling, "the real and vital concept is that freedom is the capacity for good and evil ${ }^{8,}$.

Hence freedom in human life is the capacity to do good or evil. Evil takes the place it deserves in our understanding of what freedom is since without it the concept and the living experience of freedom could never be grasped nor understood. But what is that makes evil so significant for Schelling? Probably, the fact that evil's weightiest element lies in its being a purely spiritual phenomenon which we will consider in the next part.

\section{THE SPIRITUAL NATURE OF EVIL}

One of the ground-breaking characteristics of Schelling's analysis on freedom is the importance he attaches to the profound understanding of what evil is, and of how it should be interpreted. He does not treat evil as a deficiency of the intellect principle, i.e. an incapacity of the reason to choose correctly, or as a passive attitude of the human being towards the "earthly", thus, bad, sensual instincts, nor, finally, as a lower degree of perfection, but perfection, in any case. Evil is much more complex and would not become transparent in front of the correct judgment of the reason's capacity. Evil is not to be understood in the above presented ways since it, like the human being, rises from the interplay of the two principles inside the human being, the dark and the light one, the yearning and the understanding. Finally, it is pre-eminently hard, if not impossible for evil to become transparent since it is spirit, just like us. But why is evil spiritual in its essence?

\footnotetext{
${ }^{7}$ Friedrich Schelling, Philosophical Investigations.., p. 32

${ }^{8}$ Friedrich Schelling, Philosophical Investigations...,p. 23
} 
The reason is that the human being himself, being merged into both the light and the dark principles, and having emerged from the ground of God's existence could not but be spirit. Schelling presents the spiritual coming to be of the human being in the following passage:

"Because he emerges from the Ground (is creaturely), man has in relation to God a relatively independent principle in himself; but because precisely this principle - without it ceasing for that reason to be dark in accordance with its ground - is transfigured in light, there arises in him something higher, spirit. For the eternal spirit proclaims unity or the word into nature. The proclaimed (real) word, however, is only in the unity of light and darkness (vowel and consonant)", 9 .

What we can deduct from this passage is that the spirit arises in the human being as an outcome of the interplay of the two principles inside the human being, especially if we take into account the fact that he is the only being in the universe wherein both of the principles may be in a state of interplay and of a striving to dominate one the other. In this interplay we see the emerging the human being's selfhood and the personality. How these elements appear in the interplay and which the role of each one is, are depicted in a thoughtful way in the following passage:

"The principle raised up from the ground of nature whereby man is separated from God is the selfhood in him which, however, through its unity with the ideal principle, becomes spirit. Selfhood as such is spirit; or man is spirit as a selfish [selbstisch], particular being (separated from God) - precisely this connection constitutes personality. Since selfhood is spirit, however, it is at the same time raised from the creaturely into what is above the creaturely; it is will that beholds itself in complete freedom, being no longer an instrument of the productive [schaffenden] universal will in nature, but rather above and outside of all nature" 10 .

What we see in this enlightening extract is that the dark principle, the ground, is the place where the selfhood of the human being crops up. The selfhood, however - arising in a context where the light principle as well has already emerged - has been touched by the rays of the light of the understanding, of the Word. This constant interplay is the bringing forth of the spirit and the human being's becoming a spirit. We are rising from the ground of God's existence in a world where the Word has been uttered in the most personal way; this is the matrix for our struggling to become who we really want to be. At the same time, the human being, as a particular being, as a pure selfhood, when it merges into the spirit it becomes a personality, an indissoluble merging of the selfhood with the spirit. His becoming a personality is an outstanding moment for the human being since he has become a will that is above creatures and outside of all nature. From now on human being freely decides on which his stance towards the nature the creatures and the rest of the human beings is going to be. Slavoj Zizek analysing this distinguished moment for our understanding of evil, and the human being in general, notes:

"In man as a living, actual spirit, his selfhood - which, in an animal, is merely a blind egotistic striving - comes to light. By means of this self-illumination, I become aware of myself, I 'posit' my Self in the radical exclusion of all otherness. That which, in me, resists the blissful submergence in the Good is therefore not my inert biological nature but the very kernel of my spiritual selfhood, the awareness that, beyond all particular physical and psychical features, I am 'me', a unique person, an absolutely singular point of spiritual selfreference" $" 11$.

\footnotetext{
${ }^{9}$ Friedrich Schelling, Philosophical Investigations.., p. 32

${ }^{10}$ Friedrich Schelling, Philosophical Investigations.., p. 33

${ }^{11}$ Slavoj Žižek, The indivisible remainder:An Essay on Schelling and Related Matters, London: Verso, 2007, p. 59
} 
The uniqueness of each person, and particularly, our awareness of the fact that we are unique is what hoists the human being above every creature and outside the nature. The human being, due to this profound interplay of the two principles inside him, manages to bring what was dark, the ground, into light; What was a blind will is no longer blind and from now on it can see the light of the understanding as it also sees the darkness from which it has arisen. At this moment the human being understands that he has a choice of will: willing to become one with Word and the light of the understanding, or, having seen his origin, wills to make himself the centre of the whole world's existence. The centre, which could be no other than the Word of God and the freely decided merging of the human being into it, is distorted and dislocated in the will of the human being to become the centre of the universe. This distorted will to become the centre is a purely spiritual will, since it originates from the personality of the human being, which derives from the merging of the selfhood into the spirit. Nothing could happen if there were no spirit, no light to be brought upon the depths of the ground. Schelling depicts in a radical way the birth of the sin in this free decision of the human being in the passage hereafter:

"Thus is the beginning of sin, that man transgresses from authentic Being into non- Being, from truth into lies, from the light into darkness, in order to become a self-creating ground and, with the power of the centrum which he has within himself, to rule over all things. For the feeling still remains in the one having strayed [gewichen] from the centrum that he was all things, namely, in and with God; for that reason he strives once again to return there, but for himself, and not where he might be all things, namely, in God. From this arises the hunger of selfishness which, to the degree that it renounces the whole and unity, becomes ever more desolate, poorer, but precisely for that reason greedier, hungrier, and more venomous. In evil there is the self-consuming and always annihilating | contradiction that it strives to become creaturely just by annihilating the bond of creaturely existence and, out of overweening pride [Übermut] to be all things" 12 .

Human being is rightly understood, thus, as the "being of the Centre", since it is the only being that considers itself worthy to be placed in the centre of the existence. The human being is putting himself above all the creatures, outside the law of nature, and even aspires to become the new God of the world. Evil could not be but a spiritual and human element, since only the human being can freely take the decision to put himself in the centre of the universe. No animal could ever defy the laws of nature in such an arrogant and overwhelming way the human being does. That's why evil is both free - having been freely decided as the will for the centre of the human being - and spiritual - as the event of the selfilluminating ground and its will for itself.

To reflect on what we have seen so far, the following question is to be answered: what does the human being do when he commits an evil act? A convenient response could be that he tries to become/impose his self-will on the centre of his existence taking the place of the universal will. Human being, endowed with the power of the centre he has acquired(?) over all beings, when acting evil wants to become the creative ground for everything and rule the whole existence. The latter could be described as a self-aware selfhood in the will of glorifying itself. Through his becoming aware of his own selfhood, human being can demand to become the centre of the whole creation. As long as the human being understands himself as an image of God's self-revelation, would never dare to demand the centre for himself and he would continue lurking as a potentiality in the darkness of the ground. Nevertheless, human being, having come to know himself after the illumination of his blind will by the light principle of the understanding may decide to become the centre, a purely

${ }^{12}$ Friedrich Schelling, Investigations, p. 55 
free and spiritual decision made feasible by human being's becoming aware of himself. After this act of awareness, what was a mere selfhood now sees itself as a spiritually gifted personality, since the darkness, which before the bringing of the light was a pure potentiality, through the light principle gets to actualize itself. Evil, thus, is perceived as something real, concrete and free. Evil is the human being recognizing his selfhood as a personality and willing the centre. According to Schelling:

" evil does not follow from the principle of finitude for itself but rather from the selfish or dark principle having been brought into intimacy with the centrum; and, just as there is an enthusiasm for the good, there is a spiritedness [Begeisterung] of evil " $"$.

This ceaseless interplay is what the human being is, and the only way in which he could ever be. In human life there can be no "happy ending", no last decision which will stabilize our moral standpoint once and for all. Our life can only be a constant struggle, an exhausting obligation to freely decide to will the Word as the centre instead of our purely egotistic will for ourselves.

Concluding this part, we deem important to clarify that the dark principle, just because it is dark should never be considered as such in moral terms. The dark principle is dark because what exists in it as potentiality is awaiting the light so as to come to know itself as a will and deed for actuality. If there were no dark, then there could be no enlightenment. What is dark is potentially what is brought into pure light and this is something that Schelling always bore in his mind as we can easily deduce from the beauty of the following relevant passage:

"All birth is birth from darkness into light; the seed kernel must be sunk into the earth and die in darkness so that the more beautiful shape of light may lift and unfold itself in the radiance of the sun. Man is formed in the maternal body; and only from the obscurity of that which is without understanding (from feeling, yearning, the sovereign [herrlich] mother of knowledge) grow luminous thoughts" 14 .

\section{FACING EVIL'S UPROAR IN THE MODERN WORLD}

So far, in the first two parts, we have seen the distinction between the ground of the existence of God and His existence and the way how this distinction is crucial for our understanding of how the human being, emerging from the ground, comes in touch with the understanding of the Word, making his blind will of ground a will for his own self. This distinction, then, has led us to our understanding of how freedom is to be understood in the philosophy of Schelling, at least in his Freedom Essay, and of how the choice between willing good and evil constitute the core of freedom. Finally, we have seen the importance of the spirit in the emergence of the personality of the human being which was interpreted as the possibility of choice between merging into the centre of the universal will, the Word, or human being's decision to become the new centre of the universe once the dark principle of the ground has been brought into light by the radiant light principle of understanding. In this last part we will endeavour to show the reason why Schelling's thought, and especially his Freedom Essay, not only have they not lost their philosophical power, but, on the contrary, they could offer us an invaluable aid in our coming to understand the human being as a pure will, as a being in contrast oscillating struggle between his opposite wills of freely merging himself with the universal will or trying to replace it with making it of his own will the new centre.

\footnotetext{
${ }^{13}$ Friedrich Schelling, Philosophical Investigations.., p. 40

${ }^{14}$ Friedrich Schelling, Philosophical Investigations.., p. 29
} 
There is no doubt that modern philosophy has long ago chosen a path towards a radically different vocabulary where the perception of the understanding as the selfrevelation of the Word, could, possibly, not be given its due importance because of its theological element. Nevertheless, we still do believe that both scholars of religious studies and philosophers can understand the depth of the thought of Schelling and trace its ontological importance in our better understanding what the human being is and the way the latter understands evil in his life.

In our opinion, when Schelling identifies evil with the will of the human being to bring the universal will to its knees by becoming its new centre/master, he is highlighting a really human characteristic, which is no other than the latter's way of understanding/changing the world actualized in a violent way. The $20^{\text {th }}$ century has been the century of the "titanic" or better said centrum ideas set forth into reality, no matter the cost of the human lives. The rising of the totalitarian regimes was based on their perception of a new kind of human being that would bring an end to the decadence of the western society.

The Word, especially after the Enlightenment, may have lost its space as the centre of the world, as the universal will, but this, nevertheless, has not erased humanity's necessity to believe in a universal will and try to find it in every path of its modern history. The aforementioned totalitarian regimes managed to do the same thing, and intended to legitimize in the eyes of their supporters the sacrifice of the individuals for the sake of a greater cause. Of course, no one could ever doubt that in life there are values worth fighting and worth dying for. Nonetheless, one of them should also be the realization of the uniqueness of each individual and of the unsurpassed importance of his being. When we start "sacrificing" individuals in the name of an abstract greater good the only thing we achieve is the abstraction of the individual's life where the latter becomes fuel for the machine of the greater vision's accomplishments. The (in)famous thinker Carl Schmitt uttered one harsh truth that was surely timely in his epoch, but still rings a lot of bells when examining the way modern warfare is executed:

"Here one is reminded of a somewhat modified expression of Proudhon's: whoever invokes humanity wants to cheat. To confiscate the word humanity, to invoke and monopolize such a term probably has certain incalculable effects, such as denying the enemy the quality of being human and declaring him to be an outlaw of humanity; and a war can thereby be driven to the most extreme inhumanity $" 15$.

Schelling in his analysis of the way evil appears in human condition made a philosophical and ontological breakthrough right into the core of what the human being is. The will of the centre could never be proclaimed in this way; it will get transformed into an abstract powerful ideal, a universal value which no one would dare to criticize since its intentions could never be bad - and in many cases, probably they weren't. Schelling, though, when speaking about the universal will he had in mind the self-revelation of God and our subordination to It. Now that the situation, and the validity of that claim, has radically changed, what should we expect to happen? The will for the centre still remains, but what the centre should be - a problem solved thanks to the Word for Schelling - this is indeed a question that has no easy answer, if there is one.

Having a look at the modern world we see that the indivisible remainder mentioned in the first part is extremely close to being a very realistic criterion to analyse and interpret the

${ }^{15}$ Carl Schmitt, The concept of the Political, Chicago: Chicago University Press, 2008, p. 54 
world. Every day, thousands of people die. Wars are raging all around us. The last, bloody example was the Arab Spring when the effort of introducing some fundamental for the western society values did not work that well; Libya is in crisis, Egypt faced terrible skirmishes in its interior which ended(?) when the control was taken by the army, whilst in Syria the Assad regime is still in war and trying to recuperate its territorial losses as a consequence of the struggle against the ISIS and the other parties/powers involved. If we had to explain the situation in one word, we would surely not choose order, nor balance. Bernard Freydberg, when analysing the Freedom Essay, insightfully mentions that:

"The whole, and humanity, must come to be understood and justified as works of art . . . without artists. The laws of art are alone without consequences. This factor might make them the most terrifying laws of all, more so than any moral commandment could ever be" 16 .

Finally, Schelling in his Freedom Essay managed to make both claims, a philosophical and theological one, namely that evil is not an external opposition, a trap set by the outside which will trick the rational agent while the latter is in a phase of passivity. Evil is within us, as a no longer blind will, but as a will willing everything for itself. Evil in the Freedom Essay is understood as a dissonance, a reversal of the role of the parts in an organic, not mechanistic whole. When evil arises then it cannot be just thrown away as if getting rid of the infected part could right all wrong. Evil is not an alien factor inside the whole of the human being; it is the disharmony, the ataxia occurring when the parts are no longer in order, no longer in unity. Evil is not an enemy at the gates trying to break through inside the human being; it is already there, as the reversal of his order:

"The positive is always the whole or unity; that which opposes unity is severing of the whole, disharmony, ataxia of forces. The same elements are in the severed whole that were in the cohesive whole; that which is material in both is the same (from this perspective, evil is not more limited or worse than the good), but the formal aspect of the two is totally different, though this formal aspect still comes precisely from the essence or the positive itself. To recognize this kind of being is impossible for dogmatic philosophy because it has no concept of personality, that is, of selfhood raised to spirit, but rather only the abstract concepts of finite end" 17 .

\section{CONCLUSION}

In conclusion, taking all the above mentioned into account, what we have tried to do in this paper, is to bring the issue of evil, freedom and human personality into the field of both philosophy and religion; of human being not as an abstract idea getting developed throughout the history as Spirit, but as a living being that wills strong and suffers stronger and deeper. Both religion and philosophy could play a crucial role in our understanding the way the world is, if there is an order in this world and how the human being is to behave when being afraid/conscious of the apparent lack of this order. Unfortunately, if we take a look at the globe the question we could easily ask is not whether evil is a tool for the final victory of good, but if good is the small "breaktime" in a world dominated by evil and by more and more people willing to become the centre of the former.

\footnotetext{
${ }^{16}$ Bernard Freydberg, Schelling's dialogical Freedom Essay, Albany: State University of New York Press, 2008, p. 95

${ }^{17}$ Friedrich Schelling, Investigations, p. 38
} 


\section{REFERENCES:}

[1] Freydberg, Bernard, Schelling's dialogical Freedom Essay, Albany: State University of New York Press, 2008

[2] Heidegger, Martin, Schelling's treatise on the essence of human freedom, Ohio: Ohio University Press, 1985

[3] McGrath, S,J, The Dark Ground of Spirit: Schelling and the Unconscious, London: Routledge, 2012

[4] Schelling, Friedrich, Philosophical Investigations Into the Essence of Human Freedom (translated by J. Love and J. Schmidt), Albany: State University of New York Press, 2006

[5] Schmitt, Carl, The concept of the Political, Chicago: Chicago University Press, 2008,

[6] Wirth, Jason, The conspiracy of life: Meditations on Schelling and His Time, Albany: State University of New York Press, 2003

[7] Žižek, Slavoj, The indivisible remainder: An Essay on Schelling and Related Matters, London: Verso, 2007 , 